captured. I send you short descriptive differences, whereby any one can ascertain which species he possesses, and should any one be able to give the locality of zonatus, and satisfactory evidence of its capture, the question will be at once decided."

Mr. O. Janson has a specimen from the late Mr. Chant's collection. Gallicus, Muls., is a synonym of abdominalis, Ménétr., and zonatus, Schmidt, apparently another synonym. The continental zonatus, Germ., being a separate species.

Like the preceding species, I have heard of no recent captures, and the matter seems to stand as Mr. F. Smith left it in the Zoologist, for September, 1848. However, both $R$. ochraceus and T. abdominalis are in all the British catalogues, viz., G. R. Waterhouse, 1858, G. R. Crotch, 1863, E. C. Rye, 1866, David Sharp, 1871, F. P. Pascoe, 1882, and Sharp's 2nd Edition, 1883, besides Matthews' and Fowler's.

Deal : February 7 th 1885.

\title{
DESCRIPTIONS OF A NEW GENUS AND SOME NEW SPECIES OF PHYTOPHAGOUS COLEOPTERA.
}

\section{BY MARTIN JACOBY.}

\section{Cryptocephalus interstitialis, sp. nov.}

Robust, oblong, narrowed behind. Below greenish-black, closely pubescent. Thorax, femora, and base of the tibiæ, fulvous. Elytra metallic-green, deeply and closely punctate-striate, the interstices sub-costate, finely punctured and wrinkled.

Length, 4 lines.

Hab.: Madagascar (Majunga).

Head greenish-black, the sides strongly punctured, the middle with a longitudinal groove, lower part of face covered with adpressed, whitish, long pubescence. Eyes large, triangularly notched. Palpi, and the two or three basal joints of the antennæ fulvous, the latter extending slightly beyond the base of the elytra, their third and the two following joints slender, sub-equal, the rest shorter, black, slightly thickened. Thorax transverse, greatly narrowed and deflexed in front, the sides nearly straight, posterior margin concave, its median lobe distinctly bidentate; surface extremely finely and closely punctured, the punctures slightly elongate, fulvous, extreme posterior margin piceous, serrate throughout. Scutellum sub-quadrate, black, punctured at the sides. Elytra not wider at the base than the thorax, distinctly narrowed behind, of a metallic greenish-bronze colour, each elytron with ten regular rows of deep and closely placed punctures, which, at the posterior portion, are transversely aciculate or wrinkled, the interstices very closely and finely punctured, obsoletely raised, more distinctly convex at the sides. The apex of each elytron slightly produced in a roundea point. Legs robust, fulvous, the apex of the tibiæ and the tarsi black. Prosternum broad, square-shaped. Last abdominal segment with a deep transverse forea. Pygidium broadly truncate at its apex. 
The single specimen of this large and well-marked species, which is contained in my collection will, I think, have to be placed in Suffrian's first Group of African Cryptocephali, near C. tridentatus, Klug., from which it differs sufficiently in its larger size, different coloration, and closely and finely punctured thorax.

\section{Asernoides, nov. gen., Chrysomelina.}

Sub-quadrate-ovate, convex ; third joint of maxillary palpi scarcely shorter than the fourth, the latter transversely shaped; its apex obliquely truncate. Antennæ slender and elongate, the apical joints flattened, the second joint half the length of the third, the fourth shorter than the preceding one. Thorax transverse, about three times as broad as long, its angles acute and produced, surface flattened, the sides thickened and limited interiorly by a deep longitudinal and sinuate forea. Scutellum triangular. Elytra convex anteriorly, from there to the apex quickly depressed, surface regularly punctate-striate. Prosternum elongate, its surface broadly flattened, not produced in front, its basal margin deeply emarginate. Mesosternum very narrowly transverse, convex. Metasternum longitudinally grooved. Legs long and slender, the tibiæ not channelled. Posterior first tarsal joint as long as the two following united. Claws bifid, the inner division long and pointed.

This rather remarkable genus seems somewhat allied to Eisernia in the shape of the thorax and its lateral grooves or foveæ, as well as in the emargination of the base of the prosternum. It differs, however, in its totally different general shape, and the deeply bifid claws. The coloration of the only species known to me is also rather different from most other Australian forms with which I am acquainted, from which the shape of the thorax and the thickened sides, as well as the slender and elongate legs, will distinguish it.

\section{Aisernoides nigrofasciatus, sp. nov.}

Below piceous; antennæ black, basal joints testaceous below ; head black; thorax piceous, closely punctured; elytra bright flavous, a spot at the shoulder, a transverse, medially widened band before the middle, extending up the suture, a deeply dentate transverse fascia below the middle, and a spot at the apex, black.

$$
\text { Length, } 5 \text { lines. }
$$

Head very closely and finely punctured, obsoletely longitudinally depressed between the eyes; antennæ extending to one-third the length of the elytra, slender, the first three joints testaceous below, the rest black, rather flattened and somewhat widened; thorax more than twice as broad as long, the sides nearly straight, a little constricted at the middle, all the angles acute and produced, the posterior ones thickened; surface closely covered with small and larger punctures, the sides much and broadly thickened, preceded anteriorly by a deep fovea and posteriorly by a longitudinal depression; scutellum impunctate; elytra wider at the base than the 
thorax, slightly constricted before the middle at the sides, convex to the extent of their first third, when viewed sideways, from there to the apex rather abruptly declining; yellow, each elytron with ten rather fine, but regular, rows of punctures, the first sutural one very short; a transverse black band much widened at the suture, and extending upwards to the base, but not to the lateral margin, is placed immediately before the middle, another band below the latter extends from the lateral margins across the elytra, this band is very wide at the sides, and deeply dentate and narrowed near the suture, widening again at the latter place; a transversely shaped spot is placed at the apex, and a smaller one at the shoulder; under-side and legs, as well as the anterior margin of the thorax, are piceous.

Hab. : South Queensland, Australia. (Two specimens are contained in my collection).

\section{Calomela (Australica) capitata, sp. nov.}

Sub-quadrate, convex, obscure metallic dark blue. Head, antennæ, and legs, rufous. Thorax closely punctured. Elytra closely geminate punctate-striate.

Length, 3 lines.

\section{Hab. : Australia, Rockhampton.}

Head closely punctured. Antennæ short, gradually dilated at the terminal joints, the six lower joints rufous, the rest fuscous. Thorax nearly three times as broad as long, the sides closely and strongly, the disc finely, punctured. Scutellum impunctate. Elytra sub-quadrate, not wider at the base than the thorax, each elytron with three double rows of punctures near the suture, the sides more closely and irregularly punctured, distinct to the apex. Under-side purplish, the last abdominal segment, as well as the legs and tarsi, rufous. Claws appendiculate.

\section{Collection Jacoby (two specimens).}

Allied in shape to $C$. pulchella, Baly, but differing in general colour and the double rows of punctures at the elytra, wbich extend upwards to the base, instead of becoming single rows, as in the allied species. The head and legs in the present species are also of a more decided rufous colour, while that of the elytra is a leaden-blue, the thorax being more of a greenish-blue.

\section{Calomela 6-maculata, sp. nov.}

Fulvous. Tibiæ and tarsi piceous. Thorax with a spot at each side, and a central band, black. Elytra metallic-blue, a spot at the base, a transverse dentate band at the middle, and another spot near the apex of each elytron, yellow.

Var., the thoracic spots very obsolete.

Length, 3 lines.

Hab. : New Guinea, Port Moresby.

Head with a few indistinct punctures, fulvous, its sides and the anterior margin edged with black. Antennæ slender, extending beyond the base of the thorax, fulvous, the terminal joints obscure fuscous, third joint distinctly longer than the 
fourth. Thorax three times as broad as long, with some deep and scattered punctures, the interstices also very minutely punctate ; at the sides a round black spot is placed, and the middle of the disc is occupied by a longitudinal black band, which is divided posteriorly in two branches. Scutellum fulvous. Elytra strongly and very regularly punctate-striate, the apex nearly impunctate; of the spots, the first is very small and placed close to the scutellum, the intermediate one is of transverse shape not extending to either margin, and has its posterior edge dentate in the middle, the third spot is of irregular rounded shape, and much larger than the first; the knees, tibiæ, and tarsi are piceous, rest of the legs and the under-side fulvous. Claws appendiculate.

Two specimens of this distinct species are contained in my collection.

Lamprolina unicolor, sp. nov.

Entirely metallic-green. Head and thorax very closely punctured. Elytra strongly and closely rugose-punctate. Length, 2-3 lines.

Hab. : Australia.

The entire upper surface of this insect is closely and strongly punctured, without any arrangements of rows. The antennæ extend to the first third of the length of the elytra, and have the last seven joints black, the rest metallic-green. The scutellum is much broader than long, and also punctured. All the characters agree with Lamprolina, but the species is of smaller size than any of the other described ones, this and the uniform green colour, together with the strong and irregular punctuation, will at once distinguish $L$. unicolor.

I received two specimens of this species from Dr. Pipitz, of Graz.

\section{Chalcolampra rufipes, sp. nov.}

Ovate, narrowed behind, æneous. Head, two basal joints of the antennæ, and the legs rufous. Tarsi black. Thorax remotely punctured. Elytra finely punctate-striate.

Length, 4 lines.

Hab. : Queensland.

Head with a few fine and scattered punctures; clypeus separated from the face by a deep angular groove, rufous, like the labrum and the rest of the head. Palpi black. Antennæ robust, black, the two basal joints rufous, third and fourth joints equal. Thorax transverse, the sides straight near the base, rounded anteriorly, posterior margin rounded and broadly produced at the middle, surface very remotely but deeply punctured, a little more closely at the sides than at the disc. Elytra finely and regularly punctate-striate, the interstices flat, extremely finely punctured, femora and tibiæ rufous.

A single specimen in my collection.

Easily distinguished from any of the other described species by the colour of the head and legs.

Phyllocharis cyanicornis, var. confluens, Jacoby. Hab. : Torres Strait.

This variety, of which six specimens are contained in my collections, has, to 
my knowledge, not been noticed by any author, the species itself, as is well known, being rather subject to variation in regard to colour. In my specimens, the elytra are entirely metallic-blue, with the exception of a narrow, more or less distinct, oblique, fulvous stripe from the shoulder to the suture below the middle, the extreme lateral and sutural margin being of the same colour anteriorly. The central black spot of the thorax is reduced to a small and narrow line. Every other character agrees with the typical form, the only one to which this variety can be referred on account of the indication given by the fulvous stripe, of the original pattern of the elytra, and the central thoracic spot. In one specimen, the elytral stripe also has vanished, and the elytra are uniform blue, with the exception of their lateral edge. Size, colour of the under-side, as well as structure, are absolutely as in the type.

\section{Melasoma nigritarsis, sp. nov.}

Testaceous; last six joints of the antennæ and the tarsi, black; tibiæ more or less piceous; thorax very minutely, elytra more strongly punctured, their lateral margin thickened. Length, 3-4 lines.

Hab. : Delagoa Bay, Africa (collected by Mrs. Monteiro).

Head with a deep triangular depression, very finely punctured when seen under a strong lens; antennæ scarcely reaching beyond the base of the thorax, the terminal joints transverse, five basal joints fulvous, the rest black; thorax more than twice as broad as long, anterior margin deeply concave, surface scarcely visibly punctured, a little more distinctly at the sides, where a row of longitudinal, rather deep, punctures is placed close to the lateral margin; elytra with the lateral margin distinctly thickened through their entire length, their surface closely and rather strongly punctured.

This species seems closely allied to $M$. livida, Stål, but differs in the colour of the tibiæ and tarsi, the more transversely shaped thorax, and its fine punctuation.

London: January, 1885.

\section{LITTLE KNOWN BRITISH ACULEATE HYMENOPTERA.}

BY EDWARD SAUNDERS, F.L.S.

Under this heading, in the Magazine for last May (vol. xx, p. 270), I called the attention of Hymenopterists to several rare and doubtful species, about which further information was much needed. Such information has come to hand in a few cases, as the result of last season's collecting, and the questions relating to the following species have been thereby partly cleared up.

\section{Pompilus pectinipes, V. d. L., $\delta$.}

I captured at Chobham, in August, two males, which, following the views of Wesmael and Thomson, are clearly referable to this 


\section{$2 \mathrm{BHL}$ Biodiversity Heritage Library}

Jacoby, Martin. 1885. "Descriptions of a new genus and some new species of phytophagous Coleoptera." The Entomologist's monthly magazine 21, 222-226. https://doi.org/10.5962/bhl.part.22007.

View This Item Online: https://www.biodiversitylibrary.org/item/36504

DOI: https://doi.org/10.5962/bhl.part.22007

Permalink: https://www.biodiversitylibrary.org/partpdf/22007

\section{Holding Institution}

Smithsonian Libraries

\section{Sponsored by}

Smithsonian

\section{Copyright \& Reuse}

Copyright Status: NOT_IN_COPYRIGHT

This document was created from content at the Biodiversity Heritage Library, the world's largest open access digital library for biodiversity literature and archives. Visit BHL at https://www.biodiversitylibrary.org. 